\title{
Pengaruh Konsentrasi Ethephon dan Suhu Penyimpanan pada Proses Degreening Buah Jeruk Siam (Citrus nobilis Lour var. microcarpa)
}

\section{The Effect of Ethephon Concentration and Storage Temperature in The Degreening on Siam Citrus Fruits (Citrus Nobilis Lour Var. Microcarpa)}

\author{
Ali Muhamad Prabowo, IBP Gunadnya*, I Nyoman Sucipta \\ Program Studi Teknik Pertanian, Fakultas Teknologi Pertanian, Universitas Udayana, Badung, Bali, Indonesia \\ *email: gunadnya@unud.ac.id
}

\begin{abstract}
Abstrak
Tujuan dari penelitian ini adalah untuk mengetahui pengaruh degreening dengan berbagai konsentrasi etephones terhadap kualitas buah jeruk selama penyimpanan. Penelitian ini menggunakan desain acak lengkap (RAL) dengan dua faktor perlakuan. Faktor pertama adalah empat level konsentrasi ethephon yaitu $400,500,600$, dan $700 \mathrm{ppm}$. Faktor kedua adalah suhu penyimpanan terdiri dari 2 level $\left(28 \pm 2^{\circ} \mathrm{C}\right.$ dan 18 $\pm 2{ }^{\circ} \mathrm{C}$ ). Analisis varian menunjukkan bahwa interaksi berbagai konsentrasi etephon dalam proses degreening dan penyimpanan suhu yang dipengaruhi signifikan adalah $(\mathrm{p}<0,05)$ pada penurunan berat buah, total padatan terlarut, perbedaan warna, vitamin $\mathrm{C}$ dan total asam. Hasil penelitian menunjukkan bahwa kombinasi perlakuan penyimpanan suhu rendah dengan konsentrasi $700 \mathrm{ppm}$ etephon adalah perlakuan terbaik untuk membentuk warna oranye pada kulit jeruk dan mempertahankan umur simpan buah jeruk.
\end{abstract}

Kata kunci: jeruk, degreening, konsentrasi etefon, suhu penyimpanan, warna kulit

\begin{abstract}
The purpose of this study was to determine the effect of degreening with various concentrations of ethephones on the quality of citrus fruits during storage. This study used a completely randomized design (CRD) with two treatment factors. The first factor was four levels of ethephon concentration is 400,500 , 600 , and $700 \mathrm{ppm}$. The second factor was storage temperature consisted of 2 levels $\left(28 \pm 2{ }^{\circ} \mathrm{C}\right.$ and $18 \pm 2$ $\left.{ }^{\circ} \mathrm{C}\right)$. Variant analysis showed that the interaction of various concentrations of ethephon in the degreening and temperature storage process affected significant is $(\mathrm{p}<0.05)$ on decreasing fruit weight, total soluble solids, colour different, vitamin $\mathrm{C}$ and total acid. The results showed that the combination of low temperature storage treatment with a concentration of $700 \mathrm{ppm}$ ethephon was the best treatment to form orange color on orange peel and maintain the shelf life of citrus fruits.
\end{abstract}

Keywords: citrus, degreening, concentration of ethephon, storage temperature, peel colour

\section{PENDAHULUAN}

Jeruk merupakan salah satu komoditas hortikultura yang dikembangkan di Indonesia. Menurut Supartha et al., (2015), konsumsi jeruk tahun 2015 sebesar 2,73 $\mathrm{kg}^{-1} \mathrm{kapita}^{-1}$ tahun $^{-1}$ atau sebesar 696.759 ton setelah dikalikan dengan jumlah penduduk. Konsumsi jeruk untuk rumah tangga diproyeksikan meningkat selama lima tahun kedepan (2015-2019) dengan rata-rata $0,52 \%$ ton (Kementan, 2015). Secara visual, mutu jeruk nusantara yang masak masih tergolong lebih rendah dibandingkan jeruk impor karena kulit buah umumnya berwarna hijau kekuningan dan tidak seragam walaupun telah matang. Hal ini menyebabkan tingginya angka impor. Menurut Poerwanto dan Susila (2014), kulit buah jeruk yang berwarna jingga mempunyai daya tarik yang lebih tinggi dibandingkan dengan kulit buah yang berwarna hijau.

Salah satu jeruk yang digemari konsumen adalah jeruk siam (Citrus nobilis Lour var. microcarpa). Jeruk siam memiliki warna kulit yang cenderung hijau kekuningan atau warna jingga yang tidak merata. Pembentukan warna jingga pada jeruk disebabkan oleh dua zat warna, yaitu $\beta$-citaurin yang membuat warna kulit jeruk menjadi kemerahan dan $\beta$-cryptoxanthin yang membuat warna kulit jeruk menjadi kuning. Kegagalan terbentuknya warna jingga pada kulit buah jeruk di Indonesia (daerah tropis) dikarenakan pada proses pembentukan pingmen $\beta$-citaurin dibutuhkan suhu rendah $\left(15^{\circ} \mathrm{C}\right.$ $25^{\circ} \mathrm{C}$ ). Teknologi yang banyak dilakukan untuk meningkatkan warna kulit buah jeruk tropika adalah degreening (Jomori et al., 2010). Teknologi 
degreening pada buah jeruk dapat dibantu dengan aplikasi ethephon.

Ethephon adalah suatu larutan yang mengandung bahan aktif dichloroethylphosponic acid yang dapat menghasilkan etilen secara langsung pada jaringan tanaman (Arif et al., 2014). Senyawa ethephon yang dilarutkan di dalam air melepaskan etilen dalam larutan atau jaringan tanaman melalui proses reaksi hidrolisis pada $\mathrm{pH}$ netral (Lizawati, 2008). Aplikasi ethephon pada buah jeruk siam diharapkan dapat memperbaiki warna kulit buah sehingga dapat bersaing dengan jeruk impor. Namun aplikasi ethephon juga dapat mempercepat penuaan buah jeruk sehingga daya simpan buah menjadi lebih pendek.

Salah satu cara untuk menjaga mutu buah jeruk siam dengan baik adalah dengan pengendalian suhu penyimpanan. Penggunaan suhu rendah memperpanjang masa simpan karena mampu menghambat kegiatan metabolisme dan proses pematangan yang terdapat pada produk segar (Tawali, 2004). Menurut Pantastico (2003) pada suhu penyimpanan dibawah $10^{\circ} \mathrm{C}$, reaksi biokimia menurun sehingga mampu memperpanjang masa simpan produk.

Berdasarkan hal tersebut, maka penelitian ini bertujuan untuk mengetahui pengaruh konsentrasi ethephon dalam proses degreening terhadap perubahan mutu selama penyimpanan pada suhu ruang dan suhu kulkas/dingin.

\section{METODE PENELITIAN}

\section{Tempat dan Waktu Penelitian}

Penelitian ini dilakukan di Laboratorium Pascapanen, Fakultas Teknologi Pertanian, Universitas Udayana. Penelitian ini dilakukan selama 1 bulan berjalan sejak bulan Maret sampai April 2019.

\section{Alat dan Bahan Penelitian}

Alat-alat yang digunakan dalam penelitian ini antara lain plastik mika berdiameter $16 \mathrm{~cm}$ untuk menyimpan jeruk, chamber untuk merendam jeruk, air, timbangan analitik, blender, thermometer, stopwatch, showcase, colorimeter, refractometer untuk analisis total padatan terlarut (TPT), alat titrasi untuk analisis total asam dan vitamin $\mathrm{C}$, alat laboratorium, alat tulis, dan kamera.

Bahan-bahan yang digunakan dalam penelitian ini adalah jeruk siam sebanyak 288 buah, cairan ethephon dengan merk dagang Ichipon 480SL, larutan amilum, indikator phenolphthalein, larutan $\mathrm{NaOH} 0,1 \mathrm{~N}$, larutan iodium $0,01 \mathrm{~N}$, dan aquades.

\section{Rancangan Percobaan}

Rancangan percobaan yang digunakan dalam penelitian ini adalah Rancangan Acak Lengkap
(RAL) pola faktorial dengan dua faktor perlakuan (ragam konsentrasi ethephon dan suhu penyimpanan). Faktor ragam konsentrasi ethephon terdiri dari 4 taraf yaitu $400 \mathrm{ppm}(\mathrm{K} 1)$ atau kontrol, 500 ppm (K2), 600 ppm (K3), dan 700 ppm (K4). Sedangkan untuk suhu penyimpanan terdiri dari 2 taraf yaitu suhu ruang $28 \pm 2^{\circ} \mathrm{C}$ (TR) dan suhu rendah $18 \pm 2^{\circ} \mathrm{C}$ (TK). Eksperimen diulang sebanyak 3 kali untuk setiap perlakuan, sehingga diperoleh 96 unit percobaan. Setiap ulangan terdiri dari 3 buah jeruk siam. Data hasil penelitian dianalisis dengan analisis sidik ragam dan apabila pengaruh perlakuan signifikan $(\mathrm{P}>0.05)$ maka dilanjutkan dengan uji BNT.

\section{Pelaksanaan Penelitian \\ Persiapan Bahan}

Persiapan diawali dengan proses pemanenan, buah yang dipanen adalah buah yang berumur \pm 28 MSA (minggu setelah antesis) atau masak fisiologis. Buah yang sudah dipanen disortasi berdasarkan berat (300500 gram) dan warna yang seragam (hijau terang). Buah jeruk siam dipanen dari kebun petani di Desa Belancan, Kecamatan Kintamani, Kabupaten Bangli, Provinsi Bali. Setelah proses pemanenan dan sortasi awal selesai jeruk siam dibawa ke Laboratorium Pascapanen Fakultas Teknologi Pertanian Universitas Udayana. Pembuatan larutan ethephon menggunakan prinsip pengenceran.

\section{Tahap Proses Degreening dengan Aplikasi Ethephon}

Proses degreening dilakukan dengan cara mencelupkan buah jeruk selama 3 menit (waktu pencelupan selama 3 menit diperoleh dari penelitian pendahuluan) pencelupan dilakukan langsung kedalam larutan ethephon yang telah dilarutkan ke dalam air yang bersuhu rendah $18 \pm 2{ }^{\circ} \mathrm{C}$ kemudian jeruk siam yang sudah dicelupkan ditiriskan terlebih dahulu dan diangin-anginkan sampai larutan pada jeruk siam kering. Jeruk siam yang sudah diberi larutan ethephon dimasukkan kedalam wadah mika kemudian ditutup rapat lalu disimpan di showcase bersuhu rendah $18 \pm 2{ }^{\circ} \mathrm{C}$ untuk proses degreening sesuai tingkat konsentrasi ethephon selama 5 hari, setelah proses degreening berlangsung jeruk siam diberi perlakuan sesuai dengan perlakuan suhu penyimpanan.

\section{Tahap penyimpanan}

Dalam proses penyimpanan jeruk siam yang semula ditutup rapat di wadah mika kemudian dibuka karena proses degreening telah berlangsung selama 5 hari di suhu rendah $18 \pm 2^{\circ} \mathrm{C}$, kemudian jeruk siam disimpan dengan 2 perlakuan penyimpanan yaitu penyimpanan suhu ruang $28 \pm 2^{\circ} \mathrm{C}$ dan suhu rendah $18 \pm 2^{\circ} \mathrm{C}$ selama 15 hari setelah proses degreening buah. 


\section{Tahapan Pengamatan}

Pada penelitian ini pengamatan dilakukan secara objektif terhadap kontrol maupun jeruk siam yang diberi perlakuan pada hari ke 0 atau setelah 5 hari proses degreening, 5, 10, dan 15. Pengamatan secara objektif dilakukan terhadap susut bobot, warna, kadar vitamin $\mathrm{C}$, total asam dengan titrasi iodometri, serta total padatan terlarut menggunakan refractometer.

\section{Parameter yang diamati \\ Susut bobot}

Pengukuran susut bobot dilakukan dengan cara penimbangan menggunakan timbangan analitik. Pengukuran perubahan susut bobot dihitung dalam persen dengan formula berikut:

susut bobot $(\%)=\frac{W_{0}-W_{t}}{W_{0}} \times 100 \%$

$\mathrm{W}_{0}=$ berat awal produk (berat pada hari ke 0 )

$\mathrm{Wt}=$ berat buah setelah proses penyimpanan pada hari ke-t.

\section{Total padatan terlarut}

Alat yang digunakan untuk pengukuran total padatan terlarut terhadap sari daging buah adalah digital refraktometer (ATAGO PAL- $\alpha$ ) dengan satuan o Brix.

\section{Color difference}

Hal yang diamati pada pengamatan warna adalah tingkat kecerahan $\left(\mathrm{L}^{*}\right)$ dengan nilai (range $0-100$ ) yang semakin besar menunjukkan tingkat yang semakin cerah atau menuju putih. Nilai a* (range 128 sampai 127) dimana nilai a* (-) menandakan sampel semakin hijau, nilai $*(+)$ menandakan sampel semakin merah. Nilai $b^{*}$ (range -128 sampai 127) dimana nilai $b^{*}(-)$ menandakan sampel semakin biru, nilai $b^{*}(+)$ menandakan sampel semakin kuning. Adapun rumus yang digunakan untuk mengukur perbedaan sebagai berikut (Rhim et al., 1999).

$\Delta E^{*}=\sqrt{ } \Delta a^{* 2}+\Delta b^{* 2+} \Delta L^{* 2}$

Keterangan :

$\Delta \mathrm{E} *=$ perbedaan warna total,

$\Delta \mathrm{L} * \Delta \mathrm{a} * \Delta \mathrm{b} *=$ perbedaan warna dari nilai $\mathrm{L} *, \mathrm{a} *$ dan $b *$.

\section{Kandungan Vitamin C}

Kadar vitamin $\mathrm{C}$ diukur dengan menggunakan metode tirtrasi iodiometri (Sudarmaji, 1989). Analisis data kadar vitamin C dengan menggunakan rumus sebagai berikut.

Mg.100 g buah ${ }^{-1}=\frac{\text { ml iod } \times 0,88 \times F p}{\text { g sampel }} \times 100$

Keterangan : $\mathrm{ml}$ tirtrasi : volume iod $0.01 \mathrm{~N}$ yang digunakan untuk mengubah warna filtrat dari bening menjadi biru muda (ml)

fp : faktor pengenceran W sampel : berat sampel yang digunakan untuk menghasilkan filtrat (gram)

\section{Total asam tertitrasi}

Pengukuran total asam dilakukan secara titrasi menggunakan larutan $\mathrm{NaOH}$ dan analisis data total asam dengan menggunakan rumus sebagai berikut :

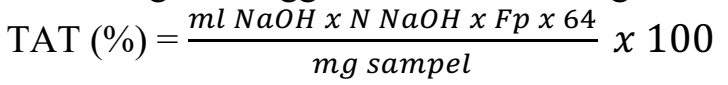

Keterangan :

$\mathrm{ml} \mathrm{NaOH}=$ Volume $\mathrm{NaOH}$ yang terpakai

$\mathrm{N} \mathrm{NaOH}=$ normalitas $\mathrm{NaOH}(0,1 \mathrm{~N})$

$\mathrm{Fp} \quad=$ faktor pengenceran (4)

$64=$ faktor asam dominan

$\mathrm{Mg}$ contoh $\quad=25.000 \mathrm{mg}$

\section{HASIL DAN PEMBAHASAN}

\section{Susut Bobot}

Hasil analisis sidik ragam menunjukkan bahwa interaksi kedua faktor berpengaruh nyata $(\mathrm{P}>0.05)$ pada penyimpanan hari ke-5, dan ke-10 dan berpengaruh sangat nyata $(\mathrm{P}>0.01)$ pada hari ke-15. Nilai susut bobot diperoleh dari selisih antara berat awal produk (sesudah di degreening) dengan berat akhir produk. Berdasarkan Gambar 1. Dapat dilihat bahwa konsentrasi ethephon 700 ppm (K4TK) cenderung memperoleh nilai susut bobot terendah jika dibandingkan dengan perlakuan konsentrasi ethephon 500 ppm (K2TK) dan kontrol. Rendahnya nilai susut bobot pada konsentrasi ethephon 700 ppm dikarenakan efek pemberian ethephon menyebabkan buah jeruk mengalami peningkatan kadar air. Menurut Anna et al. (2012) menyatakan bahwa buah yang diberi bahan perangsang pematangan ethephon menghasilkan kadar air yang lebih tinggi dibandingkan buah yang diberi bahan perangsang pematangan berupa etilen sehingga susut bobotnya lebih rendah.

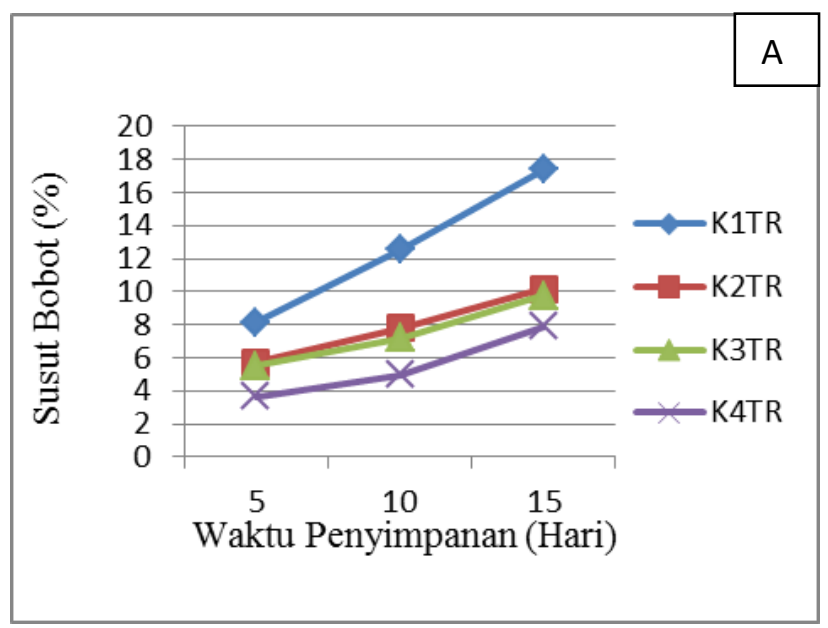




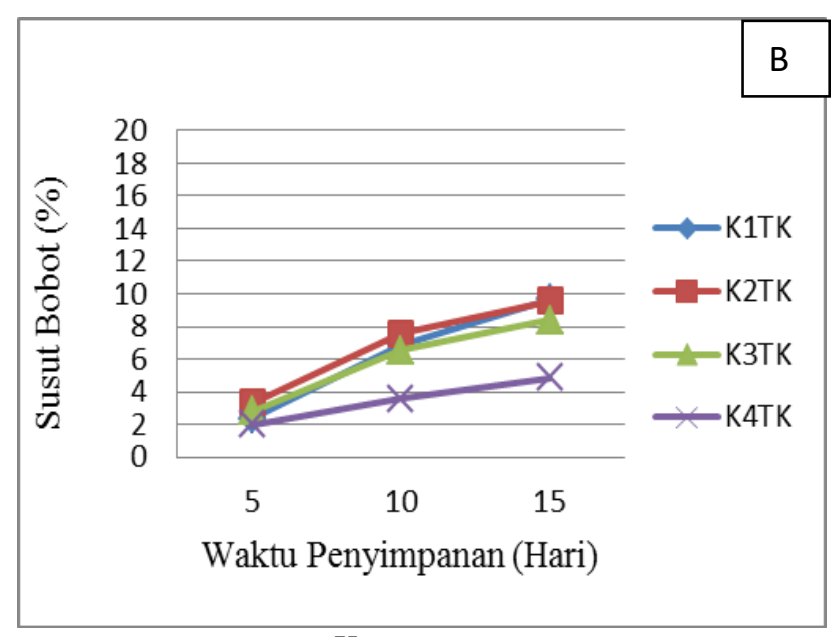

Keterangan :

Gambar a : Suhu ruang

Gambar b : Suhu dingin

Gambar 1. Pengaruh ragam konsentrasi ethephon sebagai bahan degreening dan suhu penyimpanan terhadap susut bobot buah jeruk siam pada waktu penyimpanan berbeda.

\section{Total Padatan Terlarut}

Berdasarkan analisis sidik ragam menunjukkan interaksi perlakuan suhu penyimpanan dan ragam konsentrasi ethephon berpengaruh nyata $(\mathrm{P}>0.05)$ pada penyimpanan hari ke-10, berpengaruh sangat nyata $(\mathrm{P}>0.01)$ pada hari ke-15, dan tidak berpengaruh nyata $(\mathrm{P}<0.05)$ pada hari ke-0 dan 5 .

Nilai total padatan terlarut tertinggi selama penyimpanan cendrung terjadi pada konsentrasi 700 ppm (K4TK). Besarnya nilai total padatan terlarut yang terjadi pada konsentrasi K4TK menandakan bahwa buah jeruk siam yang diberikan bahan yang dapat mengeluarkan etilen dapat meningkatkan nilai total padatan terlarut. Furqon (2017) menyatakan bahwa seiring lamanya waktu penyimpanan, kandungan padatan terlarut buah jeruk siam cenderung meningkat dan rasa buah akan semakin manis.

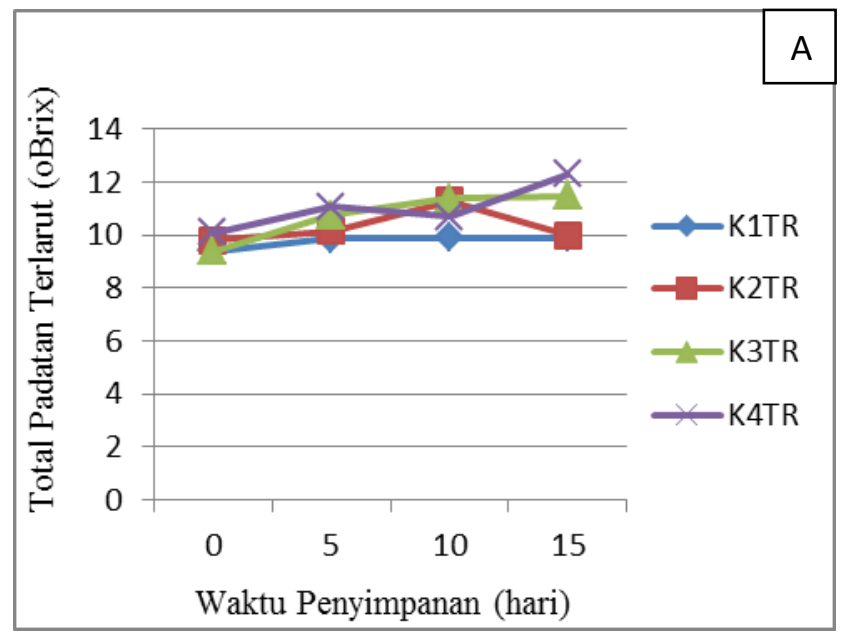

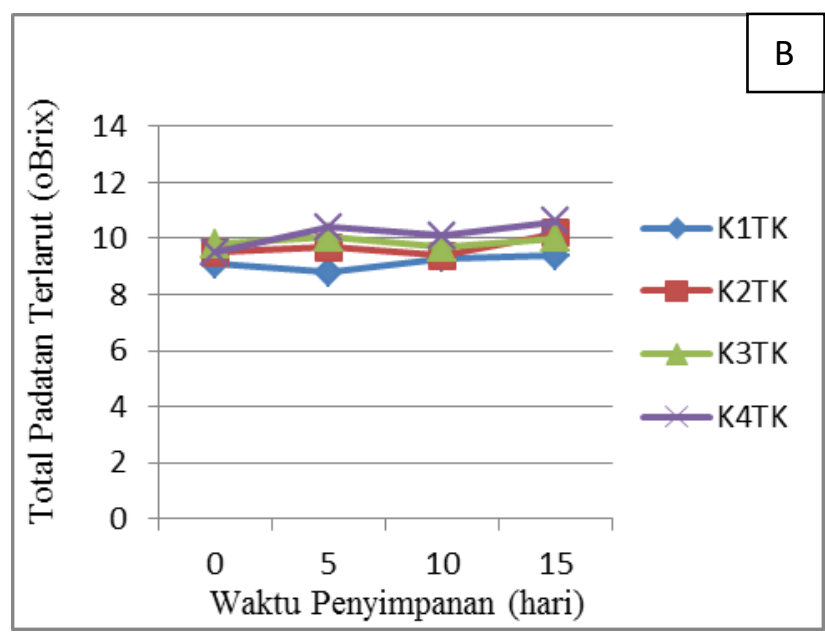

Keterangan :

Gambar a : Suhu ruang

Gambar b : Suhu dingin

Gambar 2. Pengaruh ragam konsentrasi ethephon sebagai bahan degreening dan suhu penyimpanan terhadap total padatan terlarut buah jeruk siam pada waktu penyimpanan berbeda.

\section{Colour Different $(\Delta \mathrm{E})$}

Berdasarkan analisis sidik ragam menunjukkan bahwa interaksi kedua faktor perlakuan berpengaruh nyata $(\mathrm{P}<0.05)$ pada hari ke-15, dan berpengaruh tidak nyata $(\mathrm{P}<0.05)$ pada hari ke- 0,15 , dan 10 terhadap warna kulit buah jeruk siam.

Dari hasil yang diperoleh, sampel dengan perlakuan konsentrasi ethephon $600 \mathrm{ppm}$ dan 700 ppm memiliki nilai kecerahan lebih tinggi jika dibaningkan dengan sampel perlakuan konsentrasi $400 \mathrm{ppm}$. Hasimi et al. (2016) bahwa degreening menggunakan etilen dapat mmempercepat perombakan klorofil dan mempercepat perkembangan warna buah dengan meningkatkan sintesis karotenoid.

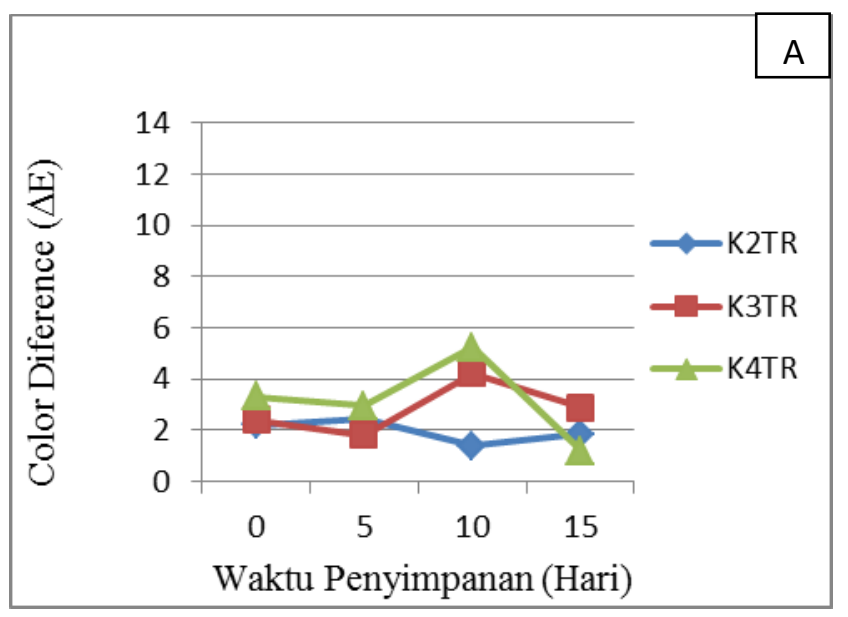




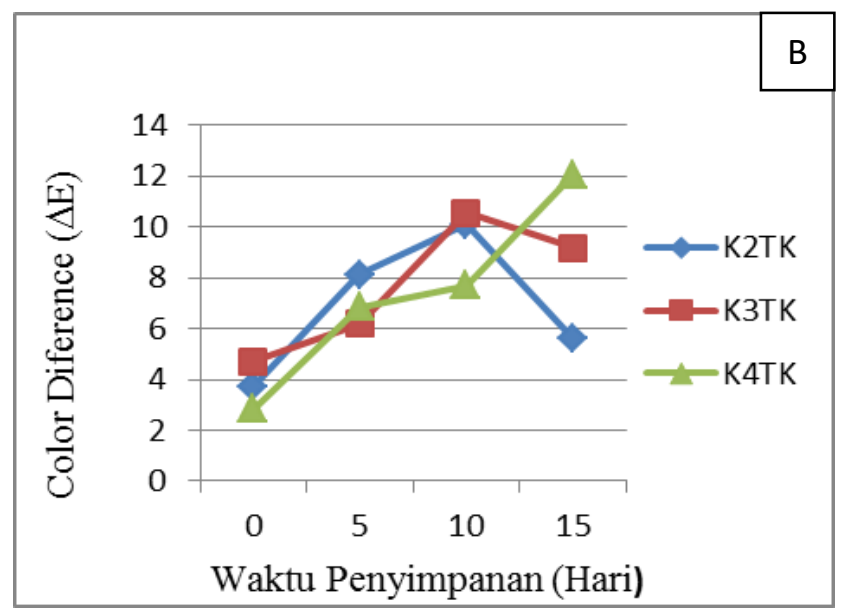

Keterangan :

Gambar a : Suhu ruang

Gambar b : Suhu dingin

Gambar 3. Pengaruh ragam konsentrasi ethephon sebagai bahan degreening dan suhu penyimpanan terhadap warna kulit jeruk siam pada waktu penyimpanan berbeda.

\section{Kandungan Vitamin C}

Berdasarkan analisis sidik ragam menunjukkan bahwa interaksi perlakuan suhu penyimpanan dan ragam konsentrasi ethephon tidak berpengaruh nyata $(\mathrm{P}<0.05)$ pada hari ke-0, 5, dan 10 dan berpengaruh nyata $(\mathrm{P}>0.05)$ pada hari ke-15.

Dari Gambar 4. dapat dilihat bahwa kandungan vitamin $\mathrm{C}$ jeruk siam cenderung mengalami penurunan selama penyimpanan. Menurut Helmiyesi et al., (2008), penurunan kandungan vitamin C disebabkan oleh degradasi vitamin $\mathrm{C}$.

\section{Total Asam Tertitrasi}

Hasil analisis sidik ragam menunjukkan bahwa interaksi perlakuan suhu dan konsentrsi ethephon berpengaruh tidak nyata $(\mathrm{P}>0,05)$ selama hari penyimpanan.

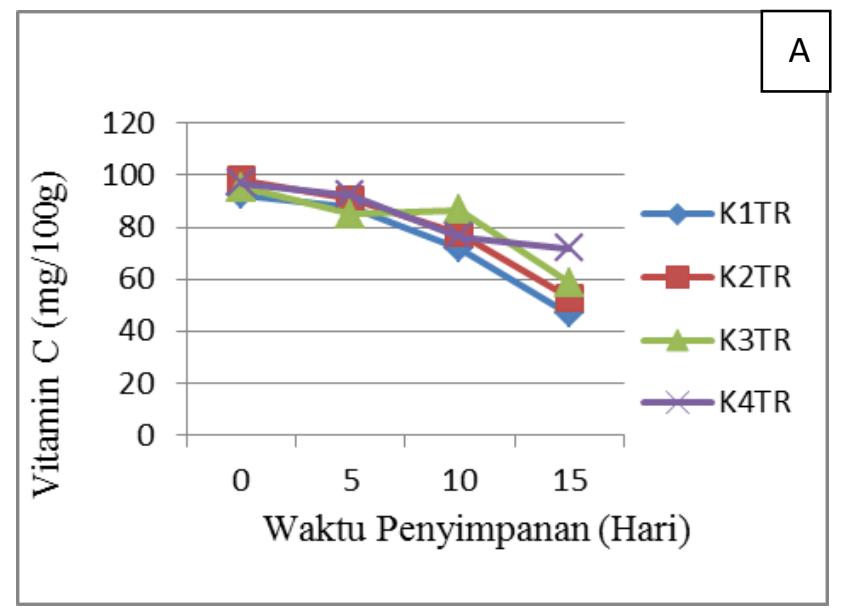

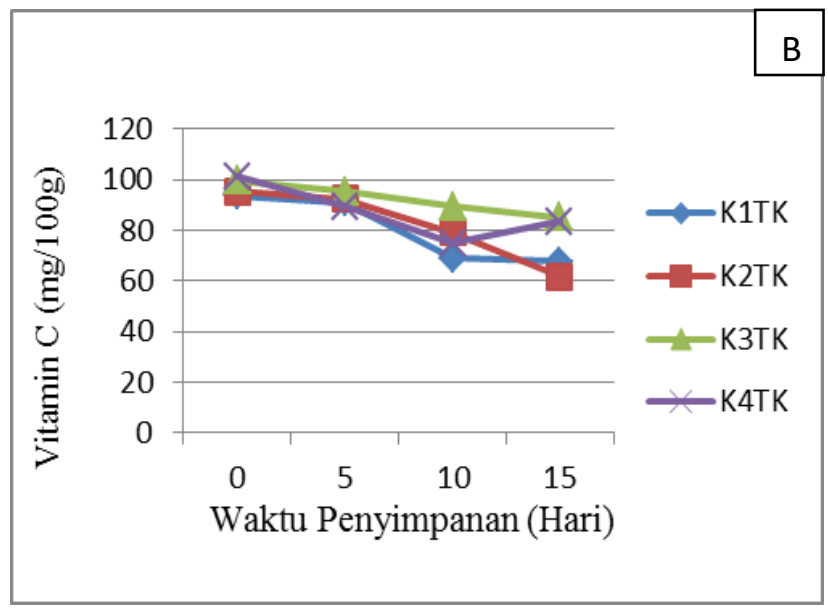

Gambar a : Suhu ruang

Gambar b : Suhu dingin

Gambar 4. Pengaruh ragam konsentrasi ethephon sebagai bahan degreening dan suhu penyimpanan terhadap kandungan vitamin $\mathrm{C}$ buah jeruk siam pada waktu penyimpanan berbeda.

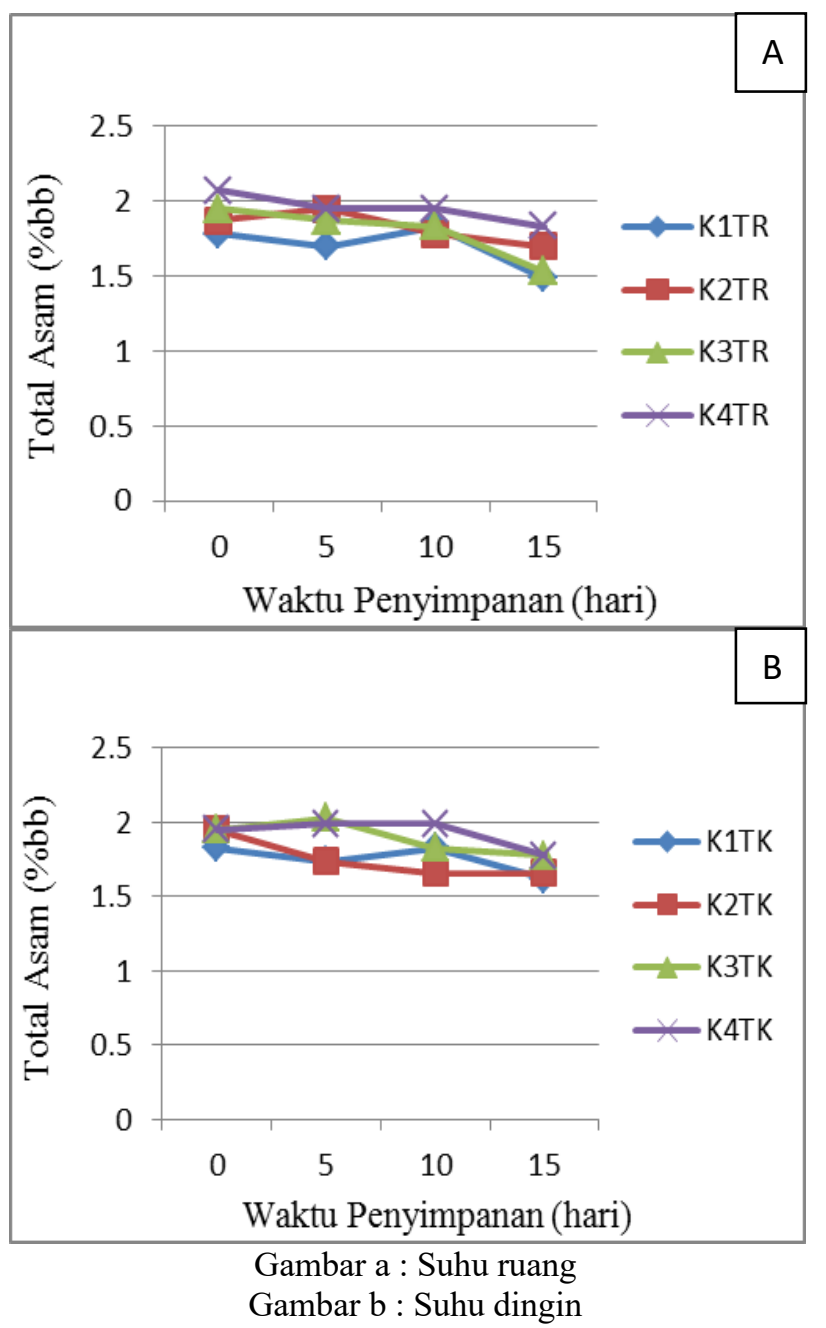

Gambar 5. Pengaruh ragam konsentrasi ethephon sebagai bahan degreening dan suhu penyimpanan terhadap total asam tertitrasi buah jeruk siam pada waktu penyimpanan berbeda.

Berdasarkan Gambar 5 dapat dilihat bahwa nilai total asam tertitrasi cenderung mengalami penurunan 
selama waktu penyimpanan. Menurut Sugianti et al. (2014), kandungan asam pada buah akan mencapai maksimum selama pertumbuhan dan perkembangan namun akan menurun selama penyimpanan. Penurunan konsentrasi asam organik dalam buah disebabkan oleh penggunaan asam organik dalam siklus respirasi krebs.

\section{KESIMPULAN DAN SARAN}

\section{Kesimpulan}

Perlakuan kombinasi konsentrasi ethephon dan masa simpan menunjukkan hasil yang berbeda sangat nyata terhadap parameter colour different, total padatan terlarut, total asam tertitrasi, vitamin $\mathrm{C}$ dan susut bobot. Konsentrasi ethephon $700 \mathrm{ppm}$ dengan suhu penyimpanan $18{ }^{\circ} \mathrm{C}$ merupakan hasil yang terbaik terhadap parameter colour different, total padatan terlarut, total asam tertitrasi, vitamin $\mathrm{C}$ dan susut bobot.

\section{Saran}

Adapun saran yang dapat diberikan berdasarkan hasil penelitian yang telah dilakukan disarankan proses degreening buah jeruk siam dilakukan pada konsentrasi $700 \mathrm{ppm}$ dengan suhu degreening dan suhu penyimpanan $18^{\circ} \mathrm{C}$.

\section{DAFTAR PUSTAKA}

Anna, P., dan Yanti, E. 2012. Pengaruh Jenis Perangsang Pematangan Terhadap Mutu Buah Terung Belanda (Cyphomandra betacea). Arif A.B., Diyono W., Syaefullah E., Suyanti, dan Setyadjit. 2014. Optimalisasi cara pemeraman buah cempedak (Artocarpus champeden). Informatika Pertanian 23 (1): 35-46.

Furqon M.A. 2017. Aplikasi precooling dan suhu simpan setelah degreening untuk peningkatan warna jingga pada buah jeruk siam (Citrus nobilis). Skripsi. Institut Pertanian Bogor. Bogor.

Hasimi N.R., R Poerwanto., dan K. Suketi. 2016. Degreening buah jeruk siam(Citrus nobilis) pada beberapa konsentrasi dan durasi pemaparan etilen. J.Hort Indonesia 7(2): 111120.

Hasmini N.R. 2017. Degreening dan pengaturan suhu simpan untuk meningkatkan kualitas buah jeruk siam (Citrus nobilis var Microcarpa) dataran rendah. Tesis. Institut Pertanian Bogor. Bogor.

Helmiyesi, H., Hastuti, R. B., dan Prihastanti, E. 2008. Pengaruh lama penyimpanan terhadap kadar gula dan vitamin $\mathrm{C}$ pada buah jeruk siam (Citrus nobilis var. microcarpa). Anatomi Fisiologi, 16(2), 33-37.Javanmardi J. and Kubota C. 2006. Variation of lycopene, antioxidant activity, total soluble solids and weight loss of tomato during postharvest storage. Postharvest Biology and Technology 41:151-155.

Juanasri dan R. Poerwanto. 2008. Pengaruh ZPT terhadap kualitas buah manggis (Garcinia mangostana L.). Agrovigor 1(1): 29-38.

Jomori, M. L. L., Sestari, I., de AM Terra, F., Chiou, D. G., dan Kluge, R. A. 2010. Degreening of'Murcott'Tangor with Ethephon Treatments. Acta horticulturae, (877), 815.

[Kementan] Kementerian Pertanian. 2015. Outlook Jeruk. Pusat Data dan Sistem Informasi Pertanian, Jakarta.

Lee, S. K. 1977. Postharvest Of Fruit And Vegetable Horticulture. Journal Of Food Technology, 32.

Lizawati. 2008. Induksi pembungaan dan pembuahan tanaman buah dengan penggunaan retardan. Jurnal Agronomi 12 (2): 18-22.

Mayuoni, L., Tietel, Z., Patil, B. S., dan Porat, R. 2011. Does ethylene degreening affect internal quality of citrus fruit. Postharvest Biology and Technology, 62(1), 50-58.

Muchtadi, T. R. 1992. Fisiologi Pascapanen Sayuran dan Buah-buahan. Departemen Pendidikan dan Kebudayaan. Jendral Pendidikan Tinggi. PAU. IPB. Bogor.

Pantastico, Er. B. 1975a. Postharvest Physiology, Handling and Utilization of Tropical and Subtotropical Fruits and Veetables. Kamariyani, (penerjemah); Gembong, T., (editor). 1997. Fisiologi Pasca Panen, Penanganan dan Pemanfaatan Buah-buahan dan Sayur-sayuran Tropika dan Sub-tropika. Cetakan keempat. Gadjah Mada University Press. Yogyakarta. 887 hal.

Pantastico, E. B. 1993. Fisiologi pasca panen, penanganan dan pemanfaatan buah-buahan dan sayur-sayuran tropika dan sub tropika. Gadjah Mada University Press.

Pantastico, E.R.B. 2003d. Fisiologi Pasca Panen, Penanganan dan Pemanfaatan Buah-Buahan dan Sayuran Tropika dan Subtropika. Terjemahan Kamariyani. UGM-Press. Yogyakarta.

Poerwanto, R., dan Susila, A. D. 2014. Teknologi Hortikultura. Bogor (ID).

Qanytah. 2004. Kajian perubahan mutu buah manggis (Garcinia mangostana L.) dengan perlakuan precooling dan penggunaan giberelin selama penyimpanan. Tesis. Insitut Pertanian Bogor. Bogor.

Rhim, J.,Wu, Y.,Weller, C., and Schnepf, M. 1999. Physical characteristics of a composite film of soy protein isolate and propyleneglycol alginate. Journal of Food Science, 64(1), 149-152. 
Sudarmaji, S. 1994. Anfalisis bahan makanan dan pertanian. Yogyakarta.

Supartha, I.W., Kesumadewi, A.A.I., Susila, I.W., Gunadi, I.G.A., dan Suari, I.D.P.O. 2015. Di dalam, Profil Jeruk Gianyar 2015. Pemerintahan Kab. Gianyar dan Fakultas Pertanian. Universitas Udayana. Bali, p.1

Tawali, A. B., Sukriani, D. A., Sifa, A., Bastian, F., dan Demmamula, S. 2004. Pengaruh suhu penyimpanan terhadap mutu buah-buahan impor yang dipasarkan di Sulawesi Selatan. Naskah Publikasi Jurusan Teknologi Hasil Pertanian UNHAS, Sualwesi Selatan. 